\title{
Impurity removal process for high-purity silica production by acid leaching
}

\author{
M. Khalifa ${ }^{\text {a }}$ M. Hajji, H. Ezzaouia
}

Laboratoire de Photovoltaïque, Centre de Recherche et des Technologies de l'Energie, Technopole de Borj-Cédria, BP 95, 2050 Hammam-Lif, Tunisie.

\begin{abstract}
In our days obtaining silica sand with very high purity is a primordial stage in photovoltaic industry. The effects of acids on the removal of impurity from silica sand have been studied using leaching acids: mixture composed of $\mathrm{HF} / \mathrm{HCl} / \mathrm{H}_{2} \mathrm{O}$ with a volume composition of $(1: 7: 24)$. The obtained material was characterized using Ultraviolet-Visible absorbance (UV-Vis) and Inductively Coupled Plasma Atomic Emission Spectroscopy (ICP-AES). Results of the application of this technique show a significant reduction of the amounts of undesirable impurities present in natural silica (such as $\mathrm{Co}, \mathrm{Fe}, \mathrm{Ca}, \mathrm{Al}, \mathrm{Mg} \ldots$...).
\end{abstract}

Keywords. Silica sand; impurity removal; acid leaching; UV-Vis.

\section{Introduction}

Crystalline silicon remains the principal material for photovoltaic technology. In spite of the innovations awaited in thin films technology, one considers that in 2030, massif crystalline silicon will account for $80 \%$ of the produced silicon solar cells. Therefore the incessant growth in the photovoltaic industry imposes a more significant production of solar grade silicon (SGS) with improved quality $[1,2]$.

The production of silicon by the thermal reduction of silica with carbon is an industrial process used since the beginning of the 20 century $[3,4,5]$. The silicon produced using this method contains many undesirable impurities. Various techniques were developed about thirty years ago to purify silicon [6-10]. These techniques are very expensive and generally cause important losses of material. To avoid those losses, to reduce the cost of the final product and to improve the purity of silicon to acceptable levels needed by photovoltaic application, one can try to purify silica using low cost techniques contributing effectively to the reduction of the final cost. Several works were carried out in this field using various techniques. Among these techniques one can cite mainly: The application of power ultrasound to the surface cleaning of silica [11], acid leaching $[12,13]$ and reverse flotation technique [14].

\section{Experimental procedure}

The silica used in this work is a natural one from the region of Siliana in Tunisia. In first time of purification, a silica was dipped for a few minutes in an acids mixture solution $\mathrm{HCl}: \mathrm{HNO}_{3}$ with

\footnotetext{
a e-mail : Khhalifa_marouan@yahoo.fr
} 
volume proportion of $(2: 1)$ to remove metallic impurities located at the surface of silica grains. Then it was abundantly rinsed with deionized water and dried under vacuum in an oven at a temperature of about $120^{\circ} \mathrm{C}$. After this surface cleaning step, the silica is partially dissolved in another acids mixture of $\mathrm{HF} / \mathrm{HCl} / \mathrm{H}_{2} \mathrm{O}$ solution with a volume composition of (1:7:24). The obtained solution is taken as a reference solution (RS). UV-visble light absorption measurements are used to evaluate the nature and the concentration of the dissolved impurities. The quantitative results were obtained from inductively coupled plasma atomic emission spectroscopy (ICP-AES) analyses.

\section{Results and discussion}

UV-vis measurements were performed by Lambda $950 \mathrm{UV}$-vis spectrophotometer. Spectra were recorded in absorbance mode in the spectral range from 190 to $1100 \mathrm{~nm}$. Prior to this characterization silica is dissolved in a $\mathrm{HF} / \mathrm{HCl} / \mathrm{H}_{2} \mathrm{O}$ solution with a volume composition of (1:7:24) until the saturation to prevent the dissolution of the quartz tank walls. The saturated solution is used for UV-Vis absorbance measurements and solid silica was filtered, rinsed and dried. The dissolved part of silica can be evaluated by gravimetric method. Figure 1 displays the evolution of the dissolved mass with the etching time. It shows that the saturation is reached after four hours of acid etching. These conditions were retained for the preparation of all solutions used for UV-Vis measurements.

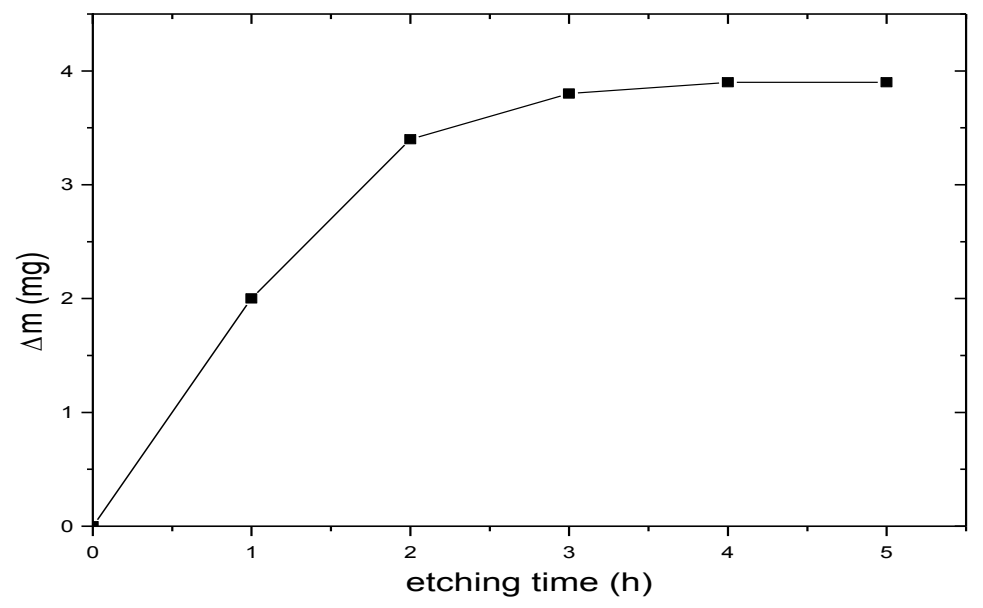

Fig.1. Evolution of the dissolved mass with the etching time

The contribution of silica to the absorbance was subtracted by using a saturated solution prepared from high purity silica as a reference during the measurement.

Figure 2 shows the absorption spectra of saturated solutions obtained after three successive dissolutions of untreated silica. The spectrum corresponding to the solution of the first leaching (curve a) reveals strong and broad UV absorption extending from 220 to $400 \mathrm{~nm}$ with a sharp band located at about $230 \mathrm{~nm}$ and second band with a lower intensity centered at about $330 \mathrm{~nm}$. This strong UV absorption is generally attributed to the presence of transition metals in materials $[15,16]$.

The spectra associated to the second leaching (curve b) shows a decrease in the intensities of both bands. This decrease is due to a diminution in the concentration of impurities contributing to the light absorption. For the third leaching we observe a supplementary decrease in the intensity of the peak located to $230 \mathrm{~nm}$ and a disappearance of the other peak. Those results indicate that the impurities are not homogeneously distributed inside the grain and have a decreasing concentration from the surface to the depth of the grain. The extinction of the band located around $330 \mathrm{~nm}$ indicates that the majority of impurities contributing to this absorption band are entirely eliminated after the third leaching. 


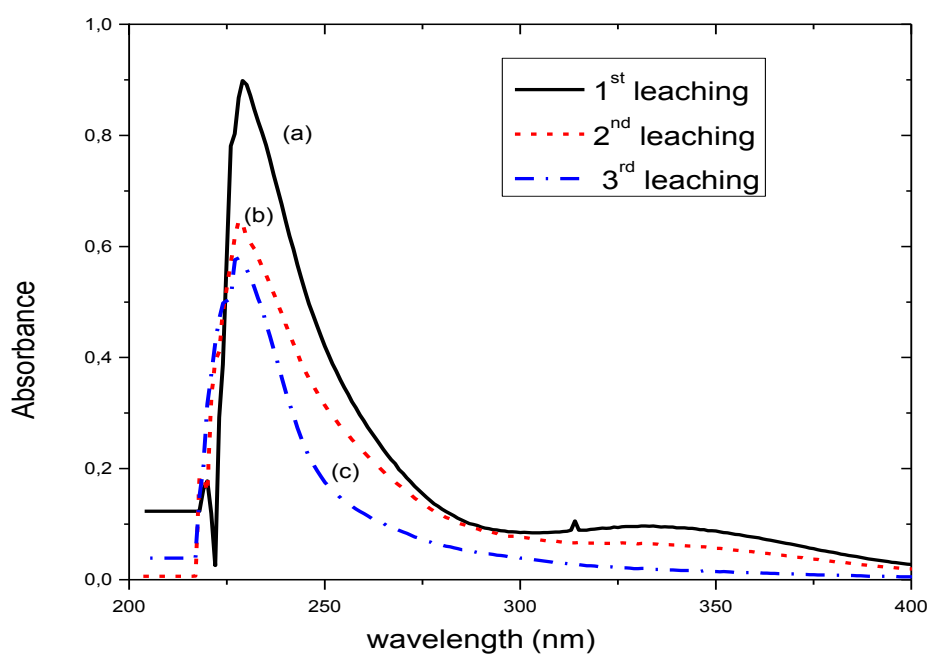

Fig. 1. UV absorption spectra of solution for different leaching

Table 1 shows the ICP-AES results for the natural silica $(\mathrm{S})$ and the chemically purified silica samples (PS). The major impurities (more than $10 \mathrm{mg} / \mathrm{kg}$ ) of the natural silica are: $\mathrm{Al}, \mathrm{K}, \mathrm{Fe}, \mathrm{Na}, \mathrm{B}$, $\mathrm{Ca}, \mathrm{Mg}$, and $\mathrm{P}$. The trace impurities (less than $1 \mathrm{mg} / \mathrm{kg}$ ) of the base silica are $\mathrm{Zn}, \mathrm{Ni}, \mathrm{Cu}, \mathrm{Cd}$. The total concentration of impurities in the natural silica is $2379.9 \mathrm{ppm}$.

Results show that after three acid leaching of silica, the total impurities concentration is reduced from 2379.9 to $1014 \mathrm{ppm}$. The concentrations of certain impurities such as P, B and Fe are slightly reduced after chemical purification process. On the other hand the aluminum concentration is largely reduced from 631 to $77 \mathrm{ppm}$ and the potassium is completely removed. This difference in the removal of impurities by acid leaching can be attributed to a difference in the reactivity of different elements and their oxides in the leaching solution.

Table 1. Concentrations (ppm) of impurities present in the silica before and after purification

\begin{tabular}{|c|c|c|c|c|c|c|c|c|c|c|}
\hline \multirow[t]{2}{*}{ Sample } & \multicolumn{8}{|c|}{ Impurities concentrations (ppm) } & \multirow[t]{2}{*}{ total } & \multirow[t]{2}{*}{$\mathrm{SiO}_{2}(\%)$} \\
\hline & $\mathrm{P}$ & B & $\mathrm{Fe}$ & $\mathrm{Ca}$ & $\mathrm{K}$ & $\mathrm{Na}$ & $\mathrm{Mg}$ & $\mathrm{Al}$ & & \\
\hline$S$ & 83 & 590 & 300 & 100 & 469.7 & 145.85 & 59.7 & 631.7 & 2379.9 & 99.76 \\
\hline PS & 50 & 300 & 153 & 184 & 0.01 & 170 & 80 & 77 & 1014 & 99.898 \\
\hline
\end{tabular}

\section{Conclusion}

The impurities in untreated and chemically treated silica were analyzed by ICP-AES method and UV-vis method. It was found that chemical treatment is very efficient in the removal of certain impurities such as aluminum and potassium. Other impurities (P, B and Fe) are moderately affected. But this method slightly affects the concentrations of other impurities. Hence, further investigations are needed to increase the purity of silica.

\section{References}

1. A. F. B. Braga, S. P. Moreira, P. R. Zampieri, J. M. G. Bacchin, P. R. Mei, Solar Energy Materials and Solar Cells 92, Issue 4, 418-424 (2008) 
2. S. Pizzini Solar Energy Materials and Solar Cells 94, Issue 9, 1528-1533 (2010)

3. V. Raman, K. Parashar and S.R. Dhakate, Journal of Sol-Gel Science and Technology 25, 175 (2002)

4. A. A. Popovich, P. A. Nikiforov, D. V. Onishchenko, A. K. Tsvetnikov, and V. G. Kuryavyi, Theoretical Foundations of Chemical Engineering, 42, number 5, 603-605 (2008)

5. B. N. Mukashev, Kh. A. Abdullin, M. F. Tamendarov, T. S. Turmagambetov, B. A. Beketov, M. R. Page, D. M. Kline, Solar Energy Materials \& Solar Cells 931785 (2009)

6. J. C. S. Pires, J. Otubo, A. F. B. Braga, P. R. Meia, Journal of Materials Processing Technology $16916(2005)$

7. C. Alemany, C. Trassy, B. Pateyron, K. -I. Li, Y. Delannoy, Solar Energy Materials \& Solar Cells 7241 (2002)

8. G. Flamant, V. Kurtcuoglu, J. Murray, A. Steinfeld, Solar Energy Materials and Solar Cells, 90 2099 (2006)

9. T. Shimpo, T. Yoshikawa, K. Morita, Metallurgical and Materials Transactions B 35277 (2004)

10. G. Flamant, V. Kurtcuoglu, J. Murray, A. Steinfeld, Solar Energy Materials \& Solar Cells 90 2099 (2006)

11. A. D. Farmer, A. F. Collings, G. J. Jameson, UltrasonicsSonochemistry 7243 (2000)

12. D. A. Barrett, V. A. Brown, R. C. WAston, M. C. Davues, P. N. Shaw, H. J. Ritchie, Journal of Chromatoghraphy A, 90569 (2001)

13. K.Y. Lee, Y. Y. Yoon, S. B. Jeong, Y. B. Chae, K. S. Ko, J. Radioanal Nucl. Chen 282629 (2009)

14. D. Mowla, G. Karimi, K. Ostadnezhad, separation and purification Technology 58419 (2008)

15. Sijian Gao, Shixi Ouyang, Tingji Wang, Journal of Materials Science 392423 (2004)

16. F. H. ElBatal, Y. M. Hamdy, S. Y. Marzouk, Journal of Non-Crystalline Solids 3552439 (2009) 